\title{
PRKACB Gene
}

National Cancer Institute

\section{Source}

National Cancer Institute. PRKACB Gene. NCI Thesaurus. Code C38411.

This gene plays a role in the regulation of diverse cell processes including cell growth, proliferation, differentiation and motility. 